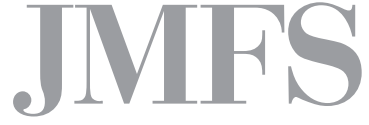

Journal of Management and Financial Sciences
Volume XI

Issue 34 (November 2018)

pp. 77-92

Warsaw School of Economics

Collegium of Management and Finance

Marta Postuła

Faculty of Management

University of Warsaw

\title{
Spending reviews as tools in the public sector
}

\author{
AbStRact
}

Worsening performance of public finance reported by a number of countries as a result of the global financial crisis enhanced interest in advanced and innovative methods of fiscal consolidation and stabilisation. Spending reviews are amongst the most comprehensive and advanced methods of this type. In the post-2008 age, spending reviews have been carried out by countries that had used the tool in earlier periods (the Netherlands, Denmark, Finland, the UK or Australia) as well as by those who started using them for the first time (Ireland, Canada and France). Spending reviews are used in countries that are well advanced economically and whose public management systems are sufficiently mature.

European Union Member States exhibit diverse interest in applying spending reviews which are not mandatory and have not been formalised in international legislation. The EU legislation contains general recommendations for the application of the rational fiscal policy enshrined first in the Treaty provisions, further developed by in the Stability and Growth Pact and detailed in 2011. The paper analyses the up-to-date experiences in using spending reviews in selected countries and draws conclusions from the process.

Keywords: public finance, spending reviews, efficiency, fiscal consolidation JEL Classification Codes: H61, H72, H20 


\section{Introduction}

Spending public resources and tools applied in the process should serve to enhance the efficiency of public services offered to citizens. Practitioners and theoreticians have identified some basic principles of rational spending of public resources, which should be substantiated with proper institutional solutions. These ten principles provide a comprehensive overview of best practices applied throughout the budget preparation process and they help to work out practical guidelines with regard to the development, implementation, and improvement of budgetary systems that can positively impact citizens' lives.

The paper focuses on one of the tools ensuring compliance with good governance criteria in the field of spending public resources, which is increasingly often used to improve the efficiency and effectiveness of public expenditure. It also attempts to draw key conclusions from spending reviews carried out across the world that might help improve the efficiency of the process in other countries and comply with the principles set out in the introduction.

The goal of the paper is to specify the rules that, if observed, can turn spending reviews into efficient management tools rather than just one more bureaucratic burden paid from public funds.

Our considerations and conclusions are based on literature studies, in particular on analyses, studies and recommendations issued by the OECD, IMF, EC, and the WB, all of which conduct annual reviews and assess procedural and institutional solutions to boost the efficiency of spending public resources on services offered to citizens.

\section{Spending reviews: definitions}

In seeking to implement modern methods of managing public resources in a country one needs to ensure that social and economic policy objectives are formulated in connection with financial projections of their delivery. This kind of integration should be seen as broken down into two closely interconnected and coherent stages of mid-term programming and task-based planning that have solid operational foundations and a subordinated task-based planning stage - overlapping with the annual budget cycle - consistent with directions, content, and the size of financing decided at strategic levels.

Apparently, what is called a spending review (or a comprehensive spending review) and has recently been the subject of systematic and intense methodological investigation and dissemination efforts, mainly of the OECD Secretariat ${ }^{1}$, is an optimal tool at the first of these levels that meets all the above-mentioned criteria.

\footnotetext{
1 For more see: Typology and implementation..., [2011,2016]; Working Party..., [2011, 2016].
} 
In its reports of 2011 and 2016 dealing with practices applied by its member countries in this area, the OECD defines spending reviews as a specific type of interim ex ante evaluation which uses the results of ex post evaluation (inter alia, efficiency information resulting from indicators used in task-based budgeting). Reviews are used for two reasons depending on their functionality profile: from the so-called strategic spending prioritization (strategic spending reviews intended to find fiscal space for high priority programmes) to functional spending reviews carried out to identify expenditure cuts opportunities within the budget process in the government sub-sector to ultimately reduce the budget deficit (in this case evaluation analyses go in-depth into the planning of tasks included in the economic programme) and indicate how these cuts are to be performed to improve the efficiency of the budget. There are also spending reviews that are both strategic and functional, such as the Comprehensive Spending Review in the United Kingdom. ${ }^{2}$

\section{Spending reviews: characteristics}

In accordance with the OECD methodology, spending reviews have the following characteristics that differentiate them from other types of ex ante evaluation exercises conducted in the public sector: ${ }^{3}$

- Spending reviews not only look at the efficiency or effectiveness of a given public intervention under current funding levels (i.e. resources earmarked for the delivery) but also investigate into potential consequences for outputs and outcomes of alternative funding levels (ex ante evaluation instruments are especially helpful, in particular the so-called evaluation questions); this functionality is particularly useful if we want to improve the so-called allocation efficiency, which aims at "improving social satisfaction through adequately shifting the outlays and changing the structure of supplies of individual public goods" [Marczewski, 2012, p. 135]. Because they belong to ex ante evaluation category, other research (analysis) criteria include significance (the degree to which objectives and tasks are pertinent to problems and needs they serve to address or satisfy) and coherence (the degree to which the internal logic of the task is maintained and the task is coherent (not conflicting) with other interventions of a similar nature) [Evaluating EU Activities..., 2004, p. 39].

- Findings concern multiannual financial programming. Spending reviews are carried out periodically and they focus on a given period (e.g., once every four years and they may be updated; there may be two different types of documents in the system which are used for different purposes).

2 For more see: Spending Review Framework [2010], HM. Treasury, http://www.official-documents.gov.uk/ document/cm78/7872/.pdf (accessed: 20.01.2017); Spending Review [2010], HM Treasury, https://www.gov.uk/ government/publications/spending-review-2010 (accessed 20.04.2017).

3 Typology and Implementation..., [2011]; Public Governance..., [2011]. 
- Responsibility for the spending review procedure rests with both the Ministry of Finance and the Chancellery of the Council of Ministers or with the Prime Minister's Office (which is a sign of a more stringent fiscal discipline, the so-called top down budgeting $)^{4}$ receiving substantive support from the "bottom", i.e., from ministries (agencies) which prepare initial spending reviews serving as input material to the overall review.

- Results of spending reviews should consistently feed into annual budget planning (because they contribute to substantial savings, e.g., in Ireland EUR 7.8 bn, in the Netherlands EUR 36 bn) [Robinson M., Spending Reviews..., 2013; Public Governance..., 2013].

- Special committees (bodies) acting in advisory capacity are crucial for the evaluation.

Spending reviews are seen not only as ways to ensure efficiency and effectiveness but also as foundations for decision-making and accountability. We need to bear in mind that there is nothing like a unified model of a spending review since the motivation behind its application and implementation process may differ a lot. There is no regularity either, when it comes to different types of spending reviews conducted in different countries and how they have evolved. A particular type of spending review, e.g., a functional review, may co-exist (or not) with an advanced type of a strategic review, with the first one usually providing an experimental/testing ground for a more advanced, strategic functionality of this management tool.

Thus, spending reviews need to be approached individually, considering the specificity of the country in question, which is crucial for optimal implementation of review objectives. We need to start with the model of strategic management of public finance which - like in mid-term planning - assumes broad involvement of the social factor in the discussion on preparing the spending review. Sometimes reviews are conducted during consultations by NGOs and, following the example of many countries which use the instrument, all interested citizens may directly submit motions. Examples of a broad public debate can be found in the United Kingdom or in the United States, where in relation with spending reviews citizens submit thousands of civil initiatives and ideas designed to improve public sector financing. This additional feature of spending reviews provides legitimisation to the economic policy of the government.

Importantly, spending reviews do not boil down to seeking ways of mechanical expenditure cutting [Marczewski, 2012, p. 80] but strive to ensure that the tools already existing within a particular financial system evolve, especially in the case of strategic and functional reviews. Such reviews, in which reference is made to objectives and measures linked with functions performed by the government or areas of its activity, are drafted based on thorough and broad analyses and strategic studies using ex ante methods and tools (based on information and recommendations resulting from ex-post evaluation of task-based budget including, inter alia, the logic of task-based budgeting and ex-ante SWOT analysis) and they emerge from

4 In the Polish Program konwergencji [Convergence Programme] (updated in April 2016, p. 40) we can find the following declaration: "In order to ensure efficient performance of the stabilising expenditure rule we will continue to strengthen the national fiscal framework by fostering the role of the top-down approach in budget planning, improving ongoing monitoring of financial situation and reporting." 
a broad debate engaging the public - typically of the evaluation culture - into diagnosing the government spending policy. ${ }^{5}$

While discussing spending reviews in a much broader context, we also analyse postulates and opinions about the government's spending policy with regard to effects of individual budget tasks presented by different circles external to the public administration. If carried out correctly, spending reviews provide a broad platform for social engagement into the budgetary process since the government undertakes special initiatives, appropriately prepared at the marketing level to encourage broad participation. They may encourage a bigger direct participation of entrepreneurs and citizens in information channels of those who spend public resources to better inform them about the needs, conclusions and efficiency initiatives formulated by representatives of those circles by which they could better contribute to the decision-making process concerning the adoption of systemic solutions.

Against this background we need to observe that government departments in countries which apply spending reviews as a rule prepare parallel initial ("partial") spending reviews based on social consultations, which are treated as additional sources of information that feed into the overall spending review drafted predominantly by the Ministry of Finance and Prime Minister's Office (or the office that offers substantive services to the Council of Ministers).

Final solutions adopted in the spending review make general references to the efficiency scale (as to the level of impact and outcomes), which could be read as the result of "juxtaposing the amount of necessary outlays" (estimated cost of the accomplishment of goals through tasks or programmes) with the "possibility of their funding" [Marczewski, 2012, p. 124].

At the same time, at this stage of advancement of the mechanism of spending reviews we witness the building up of social capital in support of such reforms. Responsibility for measurable delivery levels and motivating systems - as to the impact and interim outcomes - consists in, not always formalised, political accountability vis-à-vis the electorate and direct accountability vis-à-vis the Parliament (vote of confidence), Chief of Staff and, as a college, vis-à-vis the government. Sometimes responsibility is set out in formal documents, agreements entered into by the Prime Minister or the Minister of Finance and heads of government departments responsible for overall outcomes of their respective policies (until recently such a system of Public Service Agreements was binding in the UK). Leaving aside arguments for adopting such a solution in our country, we need to stress that agreements between the Prime Minister and ministers may positively foster the responsibility and accountability for complying with the public service obligation and, at the same time, they may incentivise decision makers to accomplish their tasks. At the operational level this role is played by executive documents which set and require certain levels of efficiency to be achieved by the management staff of public institutions (in the UK these documents are called the government's business plans and they support, in terms of information, the drafting and ensure their actual implementation;

5 For more see: Postuła [2015, 2017]. 
they are also adopted for the period that overlaps with the period of a given review) [Spending Review..., 2010, p. 9].

If periodical spending reviews become part of the management system of public resources, detailed solutions bear consequences to mid-term planning and annual budgetary planning. At this subordinated stage (when strategic solutions proposed in spending reviews get "operationalised") we need a more precise simulation of the total structure of task-based budget, i.e., its logic of interference, checking the correctness of overarching strategic objectives of the government (including their effects and impact), while comparing them to goals at lower aggregation levels with respect to the probability of accomplishing the outputs and products (in the context of resources and tools necessary to deliver the assumed objectives).

\section{Spending review: past or future}

Since the times of the global financial crisis (GFC) the OECD countries have increasingly more often been availing themselves of spending reviews. Worsening performance of public finance in many countries triggered by the GFC enhanced interest in advanced and innovative methods of fiscal consolidation and stabilisation. Spending reviews are amongst the most comprehensive and advanced methods of accomplishing these goals. In the post-2008 age, they have been carried out by countries that used the tool in earlier periods (the Netherlands, Denmark, Finland, the UK or Australia) as well as by those who started using them for the first time (Ireland, Canada, and France) [Robinson, 2013, pp. 10-11]. By looking at the list of countries who apply spending reviews we can see that the tool is used in well advanced economies whose public management systems are sufficiently mature.

From the onset of the economic and financial crisis, spending reviews have been playing a crucial role in seeking to restore the spending policy at more sustainable foundations. Yet, in most instances, the long-term objective of spending reviews is to shift from reducing fiscal disequilibrium (budget deficit) to ensuring that the outcomes of spending reviews will be systematically considered in budget-related government decisions. Spending is reviewed to expand budgetary space available to the government to accommodate new, priority policies. By systematically investigating into base spending through available information and data we may counteract the growing tendency to focus exclusively on increasing the expenditure. Spending reviews should be utilised to anchor the principles of efficiency and effectiveness in a wider budgetary process. That may be facilitated by improving the availability of respective evaluations and obtained results and by ensuring that these assessments become the core of the budgetary process. Experiences of the countries that have been using spending reviews for some time have already demonstrated that they help focus government activities to improve spending hierarchy and find fiscal space for new priority spending. Taking account of difficult budgetary reality, to many OECD countries the tool may become an invaluable instrument, especially when it becomes a lasting feature of the budget preparation process. 
In accordance with the results of the questionnaire-based studies published by the OECD in 2017, we may note an increasing number of countries using spending reviews in public management (see Figure 1). Spending reviews were used much more often following the GFC, which confirms the view that they are used, first and foremost, in fiscal consolidation and provide response to poor shape of public finances.

\section{Figure 1. Number and scope of spending reviews}

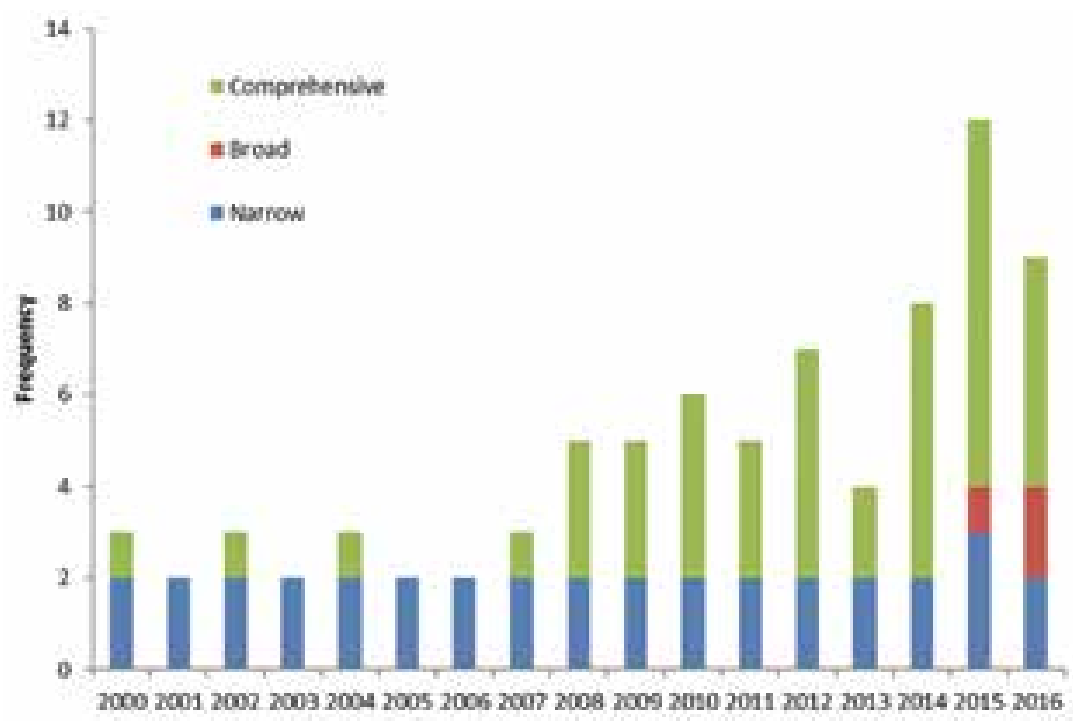

Source: OECD.

OECD countries have been using spending reviews either as an ad hoc tool, as an exercise firmly fixed within the budget process, or as an instrument used to assess the way public resources are spent. In 2016 already 23 OECD countries (as reported in the questionnaires submitted to the OECD Secretariat) were deploying spending reviews to allocate and evaluate the spending of public resources. The number of countries that claimed to have spending reviews in place significantly increased compared to 2011 when there were only 16 such countries. Further five countries are contemplating using the reviews in the future (Austria, Estonia, Israel, Norway, and Turkey) in public resource management. Over $70 \%$ of the countries that declare the use of spending reviews see them as part of the budget preparation process rather than as an ad hoc response under the heading of fiscal consolidation. If spending review procedure were to be institutionalised, it must be designed appropriately. One needs to reconsider ways in which such reviews should be built into the budget preparation process instead of being an ad-hoc instrument of greater fiscal consolidation. Moreover, since spending reviews are resource-consuming, it is crucial to approach the issue in the most rational and economical way so that costs do not exceed benefits. Taking account of the above presented differently in different countries, we adopted institutional and organisational approach to spending reviews (see Figure 2). 
Figure 2. Managing spending review process (\% of all countries that declare the use of spending reviews)

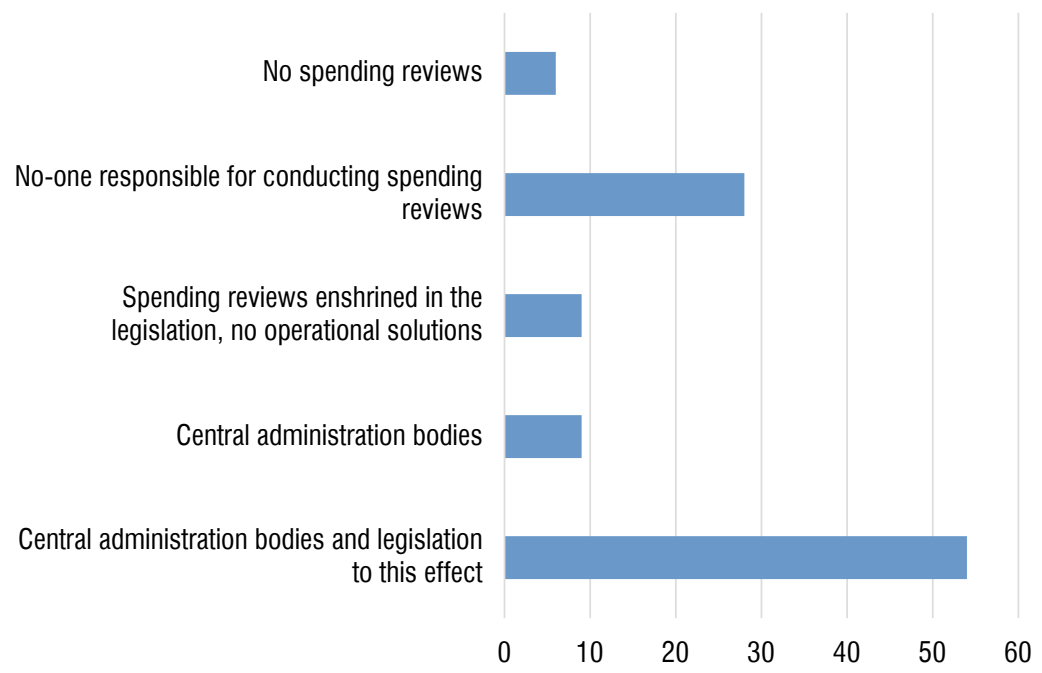

Source: Own compilation based on OECD data.

Despite their growing popularity, assessments from spending reviews are not always clearly reflected in decision-making. Ten OECD countries stated that $90 \%$ or more of their budgetary goals included in previous reviews had been accomplished (Canada, Greece, Ireland, Italy, Latvia, Luxembourg, Sweden, Switzerland, Mexico, and the United Kingdom). On the other extreme there are nine OECD countries (Australia, Denmark, Finland, France, Germany, Japan, Poland, Portugal, and the United States) which do not have any idea whether spending reviews have influenced resource allocation or any other components of the decision-making process. Unfortunately, as many as 13 OECD countries do not have any follow-up mechanisms when it comes to the accomplishment of the goals stipulated in previous spending reviews. Better monitoring of the implementation of results of reviews and its efficiency is the area where we can expect potential improvements.

Interest in using spending reviews differs across the EU Member States (as shown by the results of OECD studies) since there are no binding regulations at the international level. The EU legislation includes general recommendations to pursue rational fiscal policy, starting from the Treaty provisions developed by the Stability and Growth Pact and detailed in the Directive of 2011 on requirements for budgetary frameworks of the Member States ${ }^{6}$. The Directive addresses goals and methods of maintaining stability of public finance. However, there is no single model of conduct that would lead to the desired level of public spending and efficient fiscal consolidation on the expenditure side.

6 See: Council Directive 2011/85/EU of 8 November 2011 on requirements for budgetary frameworks of the Member States. 
ECOFIN Council of 5 March $2013^{7}$ having as a goal the improvement of public finance through inter-governmental dialogue and exchange of experience called upon the Economic Policy Committee and the European Commission to review budgetary procedures and practices boosting the efficiency of spending and lasting stability of the public sector. The Council recommended the following methods: spending reviews, task-based budget, and top-down budgeting.

The EC remarked that usually draft budget focuses mainly on discussing newly proposed spending items without reviewing sums already spent. It means there is no control over initial outlays and continuing spending budgetary resources on inefficient or low-priority programmes. Some countries (e.g., the United Kingdom, the Netherlands) systematically and rigorously examine past spending items and newly proposed ones put forward during the budget preparation process. We also need to stress that often such a "rigorous" review not only consolidates the up-till-now condition and restricts investigation into possible funding of new initiatives and strategic undertakings which call for reallocation but also constructively creates new, the so-called, fiscal space. It happens by replacing inefficient government programmes with new, perspective and innovative initiatives (programmes), which in the light of previous ex ante evaluation experience offer the best public value for money but at the same time support the implementation of ambitious, innovative, modern, growth-oriented strategic initiatives of the government [Marcel, 2014]. A Shick [2016] states directly that the intensification of resource reallocation and shifting funds between tasks or programmes implemented by spending units act as a sort of "radar" for budgeting, which signals the inefficiency of public spending. Such reallocations take place outside of the systemic and methodical supervision framework or spending reviews carried out as a centralised and top-down initiative.

Decision makers involved in the budget process must solve a number of problems to be able to correctly allocate funds and take advantage of the above-mentioned efficiency and effectiveness. These problems often originate in different sources, including political factors and rigid spending framework in the annual budget. The absence of data is the major problem since usually decision makers have limited access to information about the efficiency and effectiveness of public spending included in the budget. Moreover, they are often unaware that some ministerial programmes (implemented year in year out) do not produce expected results, nevertheless, continue to be delivered. Hence, there is little knowledge and no ideas about where these resources could be shifted or how much they should be reduced to minimise the unfavourable impact upon the scale and quality of offered services. Sometimes, many areas of management suffer from very limited access to information about tasks that are delivered efficiently. The problem can be resolved by task-based budgeting and should be presented together with information about the effects.

7 See.: Council of the EU, Press Release, 3227th Council meeting, Economic and Financial Affairs [2013], ECOFIN Council, Brussels, 5 March, p. 11. 
Similar remarks can be made about the significance of the review of budgeting efficiency. Efficiency indicators - such as a unit cost or labour productivity measures - are necessary but insufficient means to assess the efficiency of programmes and government processes. They can be seen as questions about the efficiency and effectiveness. In principle responses to them can be provided only by a thorough analysis involving efficiency assessment of the programme in question. Reliable data about the efficiency and effectiveness of spent resources are fundamental to good budgeting. Evaluation and outcomes are intended to put in order and systemise what we know about the results. Evaluation - as a specific kind of performance information - is crucial for the efficiency of the entire government budget.

Experiences of other countries making substantial efforts to deliver on both fronts reveal the real link between evaluation and task-based budgeting. In principle evaluation is necessary in a task-based budget. Almost 50 years have passed since task-based budgeting was put in place in the public administration together with the evaluation of how public resources are spent. Budget preparation process and evaluation are closely linked with task-based budgeting. One could say that task-based budget has been tied with evaluation since the moment it emerged.

\section{Advantages and disadvantages of spending reviews}

No doubt a spending review is amongst the main instruments used to evaluate public policies. Only the term "public policy evaluation" defined as an analysis of the impact of public interventions upon the condition of the economy and the population is a wider category than spending reviews. In turn, the notion "spending review" means an in-depth analysis of public spending in a given country at the level that we identified as a baseline, i.e., consistent with the legal framework and pursued policy. The main objective of such an analytical process is to improve the efficiency and generate savings by, inter alia, reducing spending on tasks not meeting legitimate needs (low priority), obsolete or inefficient. Analysis of the effects of alternative investment levels and directions, i.e., spending structure alternative vis-a-vis the baseline situation, is the principal element of the review. Spending reviews help make adjustments and reallocate resources earmarked for public tasks. Expected effects also include rational (from the viewpoint of ultimate social and economic consequences) reduction of spending to achieve the desired fiscal consolidation or the implementation of new fiscal priorities by increasing expenditure or reducing taxes.

The notion of spending review covers financial and in-kind aspects of state intervention complemented with desired changes in the spending pattern. This understanding brings us closer to the review and evaluation of the conducted public policy.

Another factor decisive for an individual approach in spending reviews is the scope of the review. The selected scope may be comprehensive or limited to one or more groups of spending. According to the OECD [Robinson, 2013, p. 15], it is practically impossible to review all public spending, which is why comprehensive reviews are understood as reviews of broader, often 
horizontal and open nature. An in-depth examination of a particular field of public intervention within a budget cycle may go beyond the capability of the available resources (administrative, analytical, financial). The scope of the review is decided ex ante. Spending areas selected for the review can be identified in terms of what the money is used for, that is, programmes or processes paid from public resources or who spends the money (a ministry, agency or other actors in the public sector). Identification of the type (comprehensive, selected) of a review and its areas (programmes, processes, entities) results from a discretionary decision of fiscal authorities of a given country and largely depends on its institutional system and procedures.

The selection of groups of expenditure subject to the review and its timetable depends on internal circumstances in a given country. In most instances, the selection also depends on the agenda of the ruling political party, selected priorities in public intervention that potentially translate into increases or reduction of public outlays in a given area. The scope of the review may also result from the coalition agreement of a few parties that are in power.

Spending reviews also investigate into tax expenditure, i.e., the burden put on the public sector as a result of preferential tax treatment. Despite different levels and structure of expenditure, fiscal systems of individual countries also differ with respect to tax allowances or other preferences, such as reduced tax rates on goods and services. Tax allowances and preferences may seriously impact the behaviour of businesses and public opinion. Their direct financial consequences are positive to taxpayers but they reduce public revenue. In many cases they provide an alternative that potentially is politically less painful than adding on a new public expenditure. However, differently from expenditure, the analysis of financial effects of tax preferences to public sector revenue is a challenging task. The estimating of the total costs of such an alternative to expenditure is difficult and less accurate than the amount of planned expenditure. Trying to find out what is the size and efficiency of tax allowances and preferences makes a substantial part of reviews. The development of expenditure as well as competitive tax scenarios is an effective way of achieving the objectives of spending reviews.

In accordance with methodological suggestion of the European Commission's experts, spending reviews take place at two levels: strategic and tactical [Thematic Review..., 2014, p. 11]. At the strategic level spending reviews examine the goals and relevance of funding particular lines of public interventions, the scope and intensity of engagement of public authorities, administration or a public entity involved in the delivery of a particular task. At the tactical level they analyse amounts spent on a particular objective, their efficiency and optimal relationship between expenditure and effect. Broader spending reviews (including comprehensive ones) deal with the strategic level but they may well be expanded to cover the tactical level. There are also spending reviews conducted at the tactical level only. The scope of reviews depends on preferences, possibilities and needs of public authorities in a given country. At the strategic as well as tactical level spending reviews do not primarily focus on general spending regulations or planning and implementation procedures but on directions of public interventions, amounts spent on them and their effects. How detailed and concrete spending reviews are in individual countries needs to be analysed on a case by case basis. 
Another selected criterion is the goal of the review, which can be a particular amount of savings, better efficiency and effectiveness with which tasks or other qualitative objectives of the policy are implemented, e.g., increased satisfaction of the recipients of public services. Even though a spending review should not be equated with automatic cuts of expenditure, its final goal may act as quantitative limitation of funding from public coffers. In terms of substance, a review necessitates a much broader procedure than expenditure cuts. We need to bear in mind that even a simple operation of reducing planned expenditure in any country is pursued taking account of local priorities and tasks excluded from the operation. That makes a spending review a more daunting and "place-based" process. The supremacy of a review over expenditure cuts comes from the possibility of treating public expenditure, which impacts economic growth, in a more flexible and preferential way. Both growth factors and growth-promoting effects of different types of public expenditure differ across national economies. This explains why a correctly carried out, in-depth and individualised review is better than mechanical expenditure cuts.

The accomplishment of the desired goals set out in the spending review closely links with how correctly and coherently these goals have been set. Qualitative goals and goals connected with efficiency may contradict quantitative goals of expenditure reduction. Contradiction can be reduced if goals are formulated, selected and possibly prioritised in a balanced and sensible way. Overly complicated procedures may involve bigger risk and ultimately higher total cost of public intervention.

For reasons pertaining to the scope and depth of analysis, spending reviews may not be applied in extraordinary circumstances and when an urgent fiscal consolidation or expenditure reduction is needed. If fiscal goals are to be achieved at an extraordinary rate, the utility and applicability of a spending review is limited.

Spending reviews are still relatively little popular despite being a rather efficient instrument of public governance. Experiences of some OECD countries and Member States of the European Union have helped to work out a coherent procedure. Reviews depend on national and local social and economic circumstances linked predominantly with the size of public spending and its structure. Differences come from different consolidation needs and fiscal stability in individual countries. Despite a similar overall methodology, detailed quantitative and qualitative goals as well as the scope and depth of spending reviews should be formulated differently.

Functional taxonomy and the structure of individual elements and groups of methods within the framework of the overall review and evaluation process, starting from ex ante evaluation which, in accordance with the intervention logic of the described governance tools, is the first, starting and necessary component of the analytical process taking the form of the most fundamental financial and economic analysis designed to provide data for more complex ex post analyses as well as for strategic studies. At this assessment level we can distinguish the Cost and Benefit Analysis (CBA), which is a method best suited for any type of executive task also appropriate for the so-called "economic evaluation" and Cost Effectiveness Analysis (CEA). 
The biggest advantage of the CBA in this case is multi-aspect ex-ante comparison of costs and benefits, including indirect benefits and long-term effects, which reflects the needs of all actors who are potentially covered by a given public intervention (programme); due to the evaluation profile of analyses discussed here everyone strives to make them as multi-dimensional as possible as this facilitates the accomplishment of set research goals and ensures the usefulness of their results for the management practice in the public sector. On the other hand, the CEA (often supported with, e.g., data envelopment analysis - DEA, i.e., multi-criteria efficiency analysis) helps find ideal models of efficiency by analysing possible solutions against many, differentiated and purposefully selected factors (e.g., environmental variables). The first from the above-mentioned links in the evaluation chain is the starting point of the overall evaluation system and a database for more complex and broader ex-post evaluations, representing the second assessment category in the system.

Ex-post analyses and evaluations are used for accountability and summing up purposes, but at the same time they make direct references to the implementation (governance), help draw conclusions and make practical recommendations for effective continuation and planning of different public policies, which, in turn, are ultimately supposed to provide information input to spending reviews. Results of ex-post assessments and analyses are based on information received from in-depth, horizontal sectoral analyses of selected public policies as well as on the impact assessment carried out of concrete public interventions or other ex-post evaluations of the efficiency and effectiveness of public administration (e.g., in the area of informatisation).

The system is complemented with the most important and the most advanced component in the managing of efficiency-related information and the use thereof, i.e., the research and evaluation segment. Within this segment we can find reviews of functional budgetary spending, the so-called limited reviews, whose main objective is to generate savings as well as less advanced methods serving the same purpose, such as the so-called lists of cost saving options, and which do not engage the analytical potential and tools from the public policy evaluation toolkit as much as saving reviews. At this highest level there are the most important, comprehensive, the so-called strategic spending reviews.

The system of analyses and efficiency evaluation is complemented with a highly specialised task-based monitoring instrument used for planning and managing the healthcare system. The latter has been singled out of the overall evaluation scheme because to assess and compare efficiency within this particular sector of public services one needs to deploy largely autonomous, strictly profiled and specialised methodology. Customised systems dedicated to the assessment of healthcare funding are also applied in other countries, e.g., in the UK and in Australia. This last and the most important component in the system reflects the latest trends in the evolution of assessment of public finance management. As demonstrated by selected OECD expert approaches, it is an ex ante evaluation category, meaning the cycle of analyses and evaluations is functionally complete so that partial data created within on-going analyses of partial assessments become an input into ex post evaluation, which provides recommendations and conclusions used to operationalise ex ante evaluations, such as spending 
reviews. All of these elements feature in the Dutch model (full cycle), including the final and the most evolutionary advanced analytical mechanism of functional and strategic spending reviews coupled with previous evaluation stages. This is indicative of highly advanced cutting edge public finance management methods applied in the Netherlands also from the multi annual perspective, making the country one of the global leaders in this area.

Undoubtedly, the ability of decision-makers to effectively seek savings and trace inefficiencies at a focused (functional) scale at the level of segments of policies, individual tasks or programmes is the precondition for success and the starting point to initiate more complex and future-oriented initiatives, i.e., to carry out strategic spending reviews investigating into spending on all public policies. The system of task-based budget introduced in Poland makes a significant contribution into developing such abilities together with the strong growth of fundamental pro-efficiency awareness and the evaluation culture; without task-based budget we would have no grass-root potential for spending reviews and the skills in the field of generating and using efficiency-related information/data as well as monitoring and evaluating the effects of tasks within the area of public finance would remain in its infancy.

\section{Summary}

Summing up the analyses discussed in this paper we may identify some pertinent principles connected with the integration of spending reviews into public management systems:

- By linking spending reviews with planning, we strengthen the impact of reviews upon the budget and we may expect better assessment of individual government programmes.

- Spending reviews "focus" the attention of units entrusted with particular tasks who are encouraged to reflect on these tasks and improve the performance.

- Periodic spending reviews help link them with the political cycle in a given country and their outcomes may provide grounds for priority change.

- At the same time, if we decide to use spending reviews, we must bear in mind that:

- Spending reviews carried out too late with respect to the implementation of the task in question are not relevant for the social and economic policy.

- Spending reviews may become an administrative burden as they engage resources and their outcomes are not taken into consideration in decision making.

- Spending reviews often have limited impact upon decisions that are taken since there are no regulations that would force out drawing conclusions from them and there are no political/administrative incentives to do so.

In conclusion, spending reviews are effective tools used in the public sector and they produce expected results when they are based on methodologically correct principles. 


\section{References}

1. Alińska A. (Ed.), 2010, Sektor finansów publicznych w warunkach światowego kryzysu finansowego. Warszawa: CeDeWu.

2. Arena M., Azzone G., 2009. Identifying Organizational Drivers of Internal Audit Effectiveness. "International Journal of Auditing", No. 13(1).

3. Byers P.Y., Wilcox J.R., 1991. Focus Groups: A Qualitative Opportunity for Researchers. "The Journal of Business Communication", No. 28.

4. Central Expenditure Evaluation Unit, Department of Public Expenditure and Reform, http:// publicspendingcode.per.gov.ie/about-us/ [accessed 19.01.2015].

5. Council of the EU, Press Release, 3227th Council meeting, Economic and Financial Affairs, 2013. ECOFIN Council, Brussels, 5 March.

6. http://www.eib.org/infocentre/publications/all/european-fund-for-strategic-investmentsin-2016.htm [accessed 20.01.2017].

7. Goodwin J., 2004. A Comparison of Internal Audit in the Private and Public Sectors. "Managerial Auditing Journal”, Vol. 19, No. 5.

8. Jong M., de, 2016. Performance-Based Budgeting: Lessons from Academic Research and Practices in the Public Sector, https://ec.europa.eu/jrc/sites/jrcsh/files/20151218PBBPresentation. pdf [accessed 16.09.2016].

9. Commission Communication to the European Parliament, Council, European Central Bank, European Economic and Social Committee, Committee of the Regions and European Investment Bank, COM(2014)903, https://ec.europa.eu/transparency/regdoc/rep/1/2014/ PL/1-2014-903-PL-F1-1. PDF [accessed 25.09.2016].

10. Marcel M., 2012. Budgeting for Fiscal Space and Government Performance Beyond the Great Recession, OECD, Paris, December, http://www.oecd.org/eco/public-finance/budgetingforfiscalspace.pdf [accessed 24.09.2016].

11. Marczewski K., 2012. Budżet zadaniowy a cele polityki gospodarczej w Polsce. [In:] P. Albiński (Ed.), Budżetowanie zadaniowe $w$ kontekście sanacji finansów publicznych $w$ krajach Unii Europejskiej, Warszawa: Szkoła Główna Handlowa.

12. Mielcarz A., 2012. Modernizacja budżetowania zadaniowego (GPRAMA) jako działania podejmowane przez administracje prezydenta B. Obamy w celu racjonalizacji finansów publicznych w Stanach Zjednoczonych. [In:] B. Woźniak, M. Postuła (Eds.), Budżet zadaniowy metoda racjonalizacji wydatków, Warszawa: Szkoła Główna Handlowa, CeDeWu.

13. Moździerz A., 2015. Strengthening the Post-Crisis Fiscal Rules - the Case of Spain, Slovakia and Sweden, "EQUILIBRIUM Quarterly Journal of Economics and Economic Policy", No. 10(2).

14. Musgrave R.A., Musgrave P.B., 1984. Public Finance in Theory and Pracitice, New York: McGraw-Hill.

15. Niemczyk W., 2014. Wspótczesne metody pomiaru efektywności funkcjonowania systemów zdrowotnych, Uniwersytet Mikołaja Kopernika w Toruniu, http://www.ue.katowice.pl/fileadmin/_migrated/content_uploads/_

16. Oręziak L., 2013. Otwarte Fundusze Emerytalne - zagrożenie dla finansów publicznych i emerytur w Polsce. IX Kongres Ekonomistów Polskich. Warszawa: PTE. 
17. Orłowski W., 2010. Ewaluacja - instrument refleksyjnego zarządzania państwem, [in:] A. Szałaj (ed.), Ewaluacja w strategicznym zarzadzaniu publicznym. Warszawa: PARP.

18. Owsiak S. (Ed.), 2011. Nowe zarzadzanie finansami publicznymi w warunkach kryzysu. Warszawa: PWE.

19. Postuła M., 2011. Budżet zadaniowy w Polsce - osiagnięcia i wyzwania na przyszłość. [In:] E. Ruśkowski (Ed.), Instrumenty nowego zarzadzania finansami publicznymi $w$ wybranych krajach Unii Europejskie., Białystok: Wydawnictwo Temida.

20. Postuła M., 2015. Instrumenty zarządzania finansami publicznymi. Warszawa: Wydawnictwo Wydziału Zarządzania UW.

21. Postuła M., 2017. Finanse publiczne $w$ architekturze współczesnej gospodarki. Teoria a polska praktyka gospodarcza. Warszawa: Difin.

22. Postuła M., 2017. Spending reviews - a tool to support efficient management of public funds. "Master of Business Administration Year 2017", Vol. 26, No. 2.

23. Public Service Reform Plan 2014-2016, 2016, http://reformplan.per.gov.ie/ [accessed 19.01.2017]).

24. Raport Polska 2030. Wyzwania rozwojowe. 2009. Zespół Doradców Strategicznych Prezesa Rady Ministrów, Warszawa.

25. Robinson M., 2013. Spending Reviews, OECD, GOV/PGC/SBO (2013) 6, Paris.

26. Ruśkowski E. (Ed.), 2011. Instrumenty nowego zarzadzania finansami publicznymi w wybranych krajach Unii Europejskiej. Białystok: Wydawnictwo Temida.

27. Shick S., 2014. Budgeting for Fiscal Space, 10 September, http://www.oecd.org/gov/budgeting/45361746.pdf [accessed 20.08.2016].

28. Schneider F., 2016. Estimating the Size of the Shadow Economies of Highly-Developed Countries. http://www.cesifo-group.info/DocDL/dice-report-2016-4-schneider-december.pdf

29. Spending Review, 2010. HM Treasury, https://www.gov.uk/government/publications/spendingreview-2010 [accessed 20.09.2016].

30. Spending Review Framework, 2010. HM Treasury, http://www.official-documents.gov.uk/ document/cm78/787/ 7872.pdf [accessed 20.01.2017].

31. Spending Review: Objectives, Design \& Processes, 2014. Ministerstwo Finansów, World Bank Seminar, Warszawa, June 2015.

32. Szołno-Koguc J., 2011. Istota i zakres reorganizacji sektora finansów publicznych $w$ świetle nowej regulacji ustawowej. [In:] S. Owsiak (Ed.), Nowe zarządzanie finansami publicznymi w warunkach kryzysu. Warszawa: PWE.

33. Drucker P.F., 2006. The Effective Executive: The Definitive Guide to Getting the Right Things Done (Harperbusiness Essentials) Paperback. Harpercollins.

34. Thematic Review on the Quality of Public Expenditure. Preparing and Implementing Spending Reviews, 2014. Brussels: DG ECFIN.

35. Working Party of Senior Budget Officials, Budget Review German., OECD, GOV/PGC/ $\mathrm{SBO}(2014) 1$, Paris.

36. Working Party of Senior Budget Officials OECD Senior Budget Officials Network on Performance and Results, 2011. 7th Conference Centre, Paris, 9-10 November. 